\title{
Technical Analysis Feasibility Study on Smart Microgrid System in Sekolah Tinggi Teknik PLN
}

\author{
Heri Suyanto \\ Lecturer, College of Engineering - PLN (Foundation for Education \& Welfare PT. PLN (Persero). PLN tower. Jl. Outer West Lingkar, \\ Duri Kosambi, Cengkareng, Indonesia 11750
}

\begin{abstract}
Nowadays application of new and renewable energy as main resource of power plant has greatly increased. High penetration of renewable energy into the grid will influence the quality and reliability of the electricity system, due to the intermittent characteristic of new and renewable energy resources. Smart grid or microgrid technology has the ability to deal with this intermittent characteristic especially if these renewable energy resources integrated to grid in large scale, so it can improve the reliability and efficiency of the grid. We plan to implement smart microgrid system at Sekolah Tinggi Teknik PLN as a pilot project. Before the pilot project start, the feasibility study must be conducted. In this feasibility study, the renewable energy resources and load characteristic at the site will be measured. Then the technical aspect of this feasibility study will be analyzed. This paper explains that analys is of ths feasibility study.
\end{abstract}

\section{Introduction}

The conditions of electricity in Indonesia is still inadequate, which the ratio of electrification is still low at $87 \%$ as of October 2015 (PT. PLN Persero). This shows that people access the energy is still limited. And also with the development of energy infrastructure in Energy for rural / remote and island - the outermost islands in general do not get adequate energy access. Dependence on electricity industry is more limited. Utilization of new and renewable energy and implementation of energy conservation are also not set optimal [1].

As the one of the way fulfil local needs for electricity, and in accordance with the policies of Indonesian government, in the past few years has been started the development of power systems of new and renewable energy (EBT) [2]. Due to the nature intermittent characteristic of new and renewable energy, we need a system to resolve the issue. Smart microgrid system or smart grid is one technology that can effectively and efficiently address the integration of new and renewable Energy in the electrical system for a large scale.

Since 2015 STT PLN has been conducting some research of smart microgrid, with stage: study potentials stats with (2015) and design of the smart microgrid laboratorium scale model (2016) [3], As the development of smart microgrid model and for application in the field, so as a first step of the implementation to start to establish the pilot project of smart microgrid system with in at the laboratory scale in STT PLN start in 2017

\section{Technical Review}

Research and development of renewable energy especially for Solar Power Generation based on smartgrid technology has been listed on RIP STT PLN 2013 2018. One of strategies to fulfill the electric energy needs is to utilize the potential of new and renewable energy (EBT) at the local site, In order to reduce transmission and distribution costs. Potential of Renewable Energy (ET) in local area is used to meet the needs of electrical energy in the area [4]. This will lead high concentration of renewable energy in into the grid. High concentrations of renewable energy sources can cause problems in stability, reliability and power quality on the main grid [5]. Smart microgrid is the key of the future grids where high concentration of renewable energy does not affect or disrupt with the quality of the grid.

A smart microgrid system can be interpreted as an electrical system consists of several Distributed Generations (DG) where the source is usually from EBT, such as photovoltaic panels, wind turbines, microturbons, with the addition of a storage system, load control, and an energy regulation system (Energy Management System - EMS). EMS allows smart microgrid systems to make its own free adjustment regardless grid positive in standalone mode (islanding). This microgrid smart system can operate in two modes, On-Grid / Gridconnected and Off-Grid / Standalone / Islanding. OffGrid / Standalone / Islanding operation mode is when circuit breaker isolates the system from the main grid (PLN), so power generator equipment, storage, load regulator, power quality controller and other system 
operation regulator are applied only to smart microgrid system [6]. In Off-Grid mode the load is supplied applied by DG, Diesel Generator (it backup) and Battery [7]. In an on-grid / grid connected mode, the microgrid smart system is also a controllable load, or the power generated from the grid is a backup / supplemental energy source. In On-Grid / Grid Connected mode this load is supplied by DG, grid (as backup) and Battery [8].

\section{Research Methods}

The expected outcome of this research program is the synergies which mutually beneficial and supportive synergies between university (STT PLN) and industrial partners to produce hybrid power plant products designed and manufactured in a micro-distributed (micro-grid structure), and Supported by high technology, so it can be operated in local/ remote island to fulfil needs of housing and also support the operation of NKRI territorial integrity [9].

Methodology and research stages to be used follow:

a. Measure New and Renewable Energy potential, the wind and solar energy at Sekolah Tinggi Teknik PLN.

b. Analysis of irradiation data on selected area (local / remote island), refers to data from BMKG and Lapan and other agencies.

c. Measure the load characteristics at the smart micro grid site.

d. Conducted an analysis of data on potential and characteristics of the load.

e. Conduct the analysis of feasibility for smart micro grid system as the technical specifications of solar cells, and determining the electrical power control system based on "power electronics" based on the study of literature [10].

\section{Results And Discussion}

Sekolah Tinggi Teknik PLN is located at Lingkar Barat, Duri Kosambi, Cengkareng, Jakarta Barat, Jakarta 11750. Applied load in the Campus main building of $100 \mathrm{KW}$, and the load in the Laboratory of STT PLN is $15 \mathrm{KW}$.

After the discussions among colleagues and professors of Sekolah Tinggi Teknik PLN and by direct observation at the location it was determined that the project smart microgrid system will be built right at Laboratory at Research and Training Center For Renewable Energy Power System. Presence of solar Laboratory will save the electricity bill from PT. PLN

Blueprint New and Renewable Energy STT PLN as follows according to Figure 1 among others as follows:

1. Solar Power Plant (PLTS) capacity $14.5 \mathrm{kWp}$

2. Bayu / wind power plant (PLTB) capacity of $20 \mathrm{~kW}$

3. Biomass Power Plant $16 \mathrm{kVA}$ consisting of:

- Waste Power Plants T gasifer 14 kVA

- Waste Power Plants digester of $2 \mathrm{kVA}$

4. With KWH Export and Import KWH meter system (Exim) from PT. PLN (Persero) and Battery

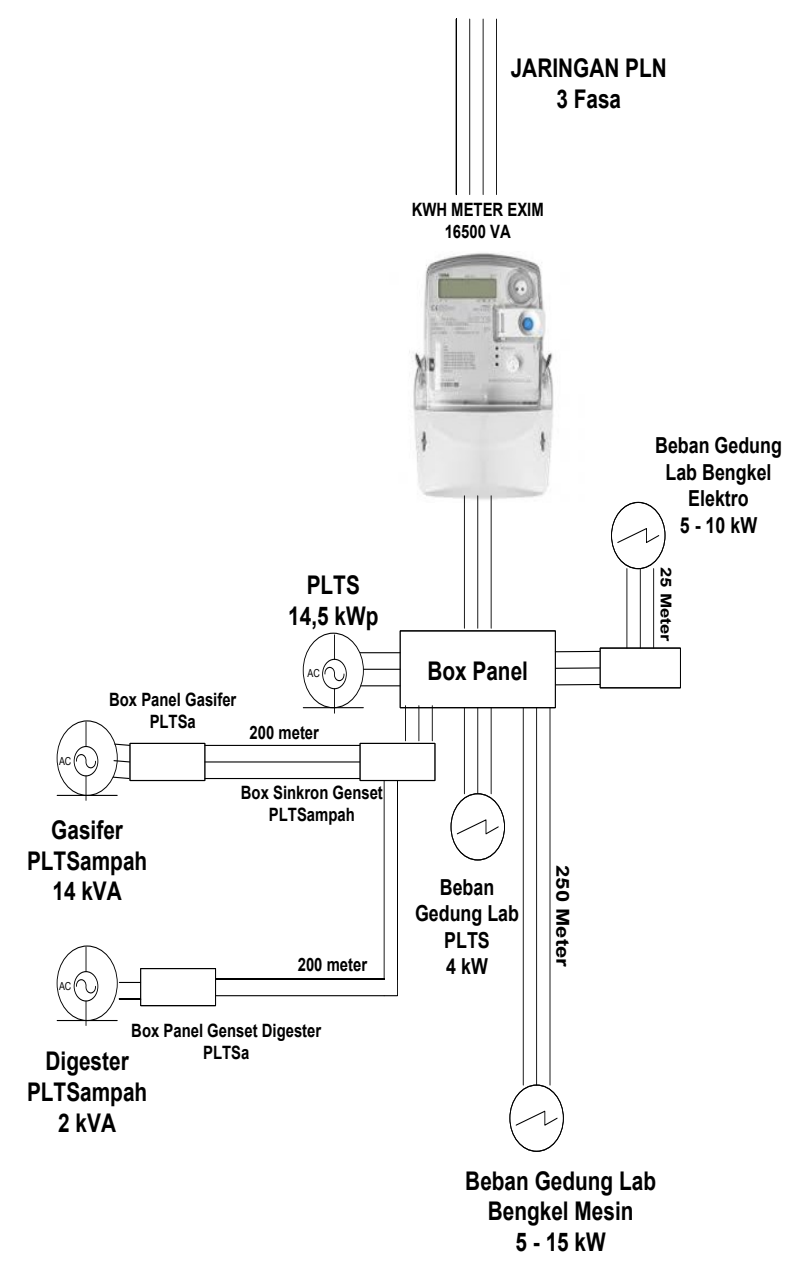

Fig. 1. Blueprint STT PLN Smart microgrid System.

This Installation that has been installed with a capacity of $14.5 \mathrm{~kW}$ with microgrid smart system On Grid and Off Grid.

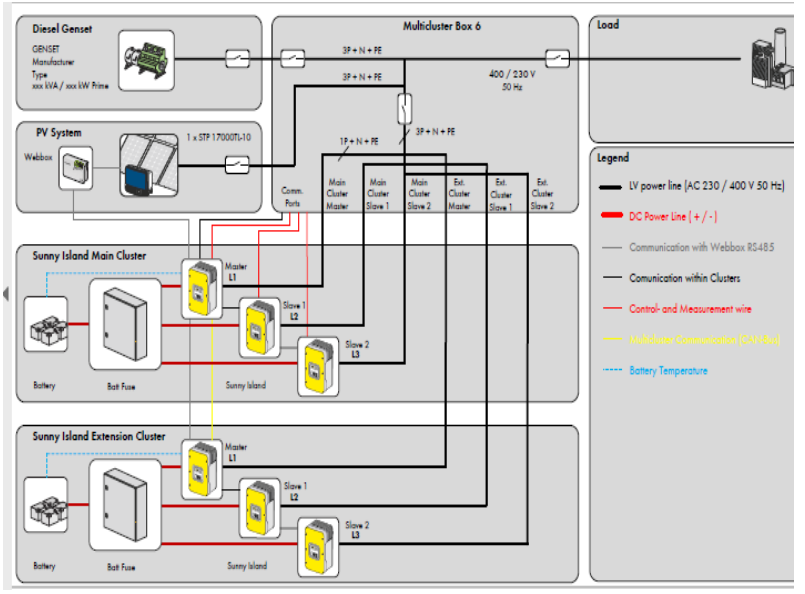

Fig. 2. Smart grid system design of Microgrid system for off grid at STT PLN

Our Solar Power Plants Capacity of $17 \mathrm{~kW} /$ peak has already Integrated KWH Meter Exim Export and Import and has installed with advanced technology monitoring system. This design is made as a Research by knowing new and renewable energy technologies especially Solar Power Generation and as a saver of 
electricity usage from PT. PLN (Persero) and the electricity cost down. Figure of generated electricity from PLTS monitoring system.

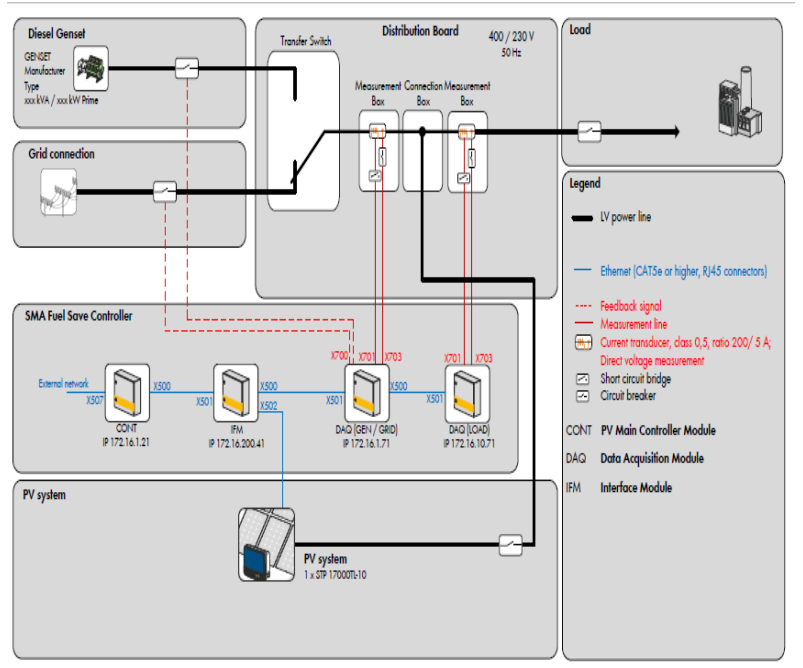

Fig. 3. Smart System Design of Microgrid system on grid at STT PLN

\section{Day Month Year Total}

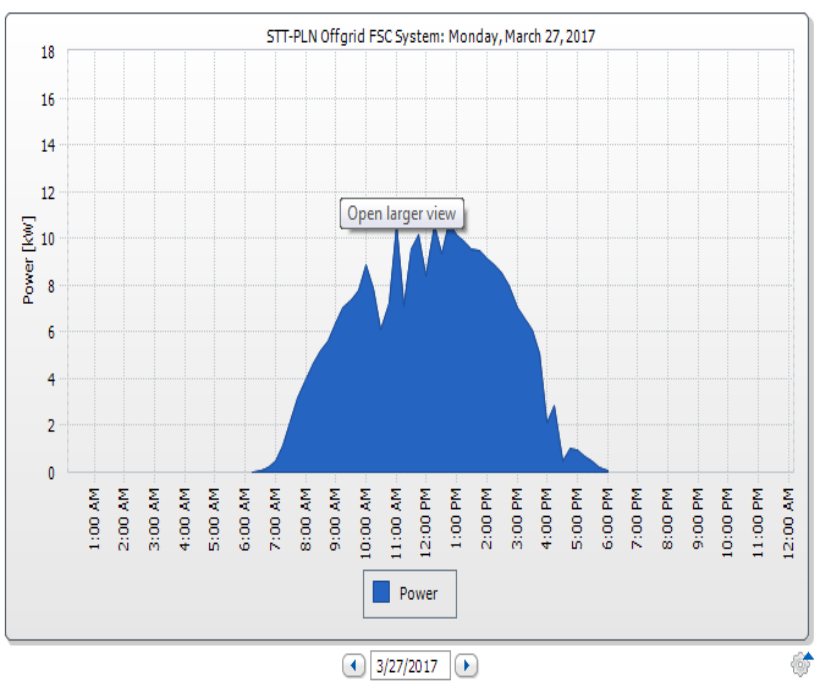

Fig. 4. Daily electricity curve of PLTS

It shows the maximum peak at 11:00 to 14:00 hours to reach $10 \mathrm{~kW}$ so that one can reach $70 \mathrm{~kW}$ in the position of maximum results Daily and Daily Average reaches $40 \mathrm{~kW}$.

From the curve above, electricity generated from Solar Power Generation can reach 1.4 MWh.and Biomass Power Plant is in the design stage For Bayu / Wind Power Generation and Biomass Power Plant is still under costumer.

This Microgrid Project Smart will be applied as Research and Learning on New and Renewable Energy at the Research and Training Center Laboratory for Renewable Energy Power System STT PLN.

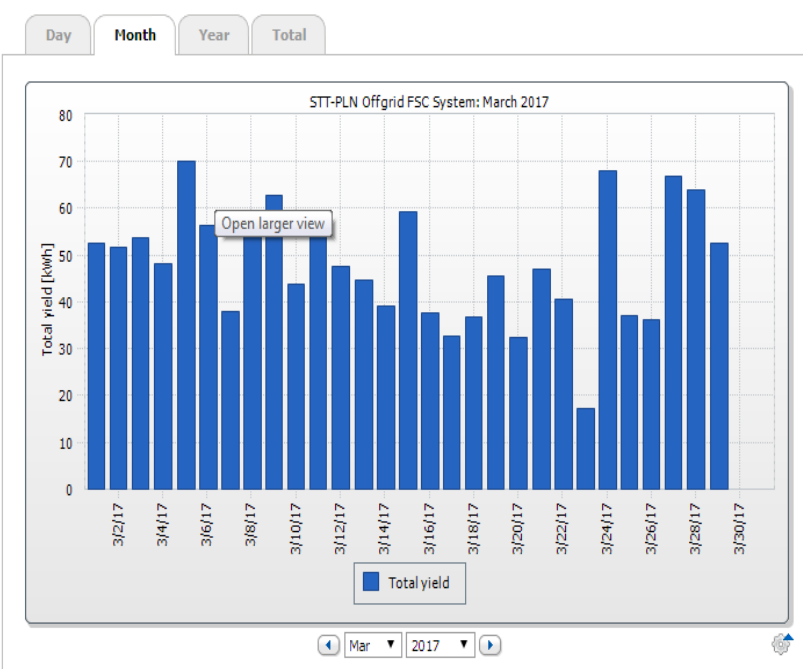

Fig.5. Monthly Electricity Curve of PLTS

\section{Conclusion}

- From the analysis conducted on the technical aspects of the feasibility study of the application of Smart Microgrid System Project in Sekolah Tinggi Teknik PLN is feasible with high potential availability and installation area of equipment as we expected.

- Microgrid Smart System Project in Sekolah Tinggi Teknik PLN Research and Training Center Laboratory for Renewable Energy Power system STT PLN as New and Renewable Energy Technology Research and as a saver of electricity usage from PT. PLN.

- Blueprint of smart microgrid system for New and Renewable Energy STT PLN consists of PLTS capacity $14.5 \mathrm{kWp}$, PLTB capacity $20 \mathrm{~kW}$, PLTbiomass with $14 \mathrm{kVA}$ Gasifer PLTS garbage and $2 \mathrm{kVA}$ of waste PLTS Digester) and Battery.

\section{References}

1. CERTS Microgrid Symposium, Northern Power Systems

2. Clarke,S., "Electricity Generation Using Small Wind Turbines At Your Home Or Farm", Fact Sheet, September (2003)

3. Jay Stuller, "An Electric Revolution”, Galvin Electricity Initiative

4. J. B. (Secretary of U. S. D. of C. P. D.G. (Director of N. I. of S. and Technology), NIST Framework and Roadmap for Smart Grid Interoperability Standards, NISTSpecial Publication 1108R2 NIST Framework and Roadmap for Smart Grid Interoperability Standards, NIST Speci. Energy Independence and Security Act of 2007, (2012).

5. Kurt Yeager, "The Microgrid Revolution", Oktober (2010) 
6. Smart Houses interacting with Smart Grids to achieve next generation efficiency and sustainability, Dr. Anke Weidlich, SAP Research 11.02.2009

7. IEC Smart Grid Standardization Roadmap, Prepared by SMB Smart Grid Strategic Group (SG3) June 2010; Edition 1.0

8. R. Ramakumar, "Integrated Renewable Energy System - Micro Grid (IRES-MG) For Sustainable
Development", ICSUNIDO, Trieste, Italy, April (2012)

9. "The Smart Grid: Coming Of Age", Electric Power Research Institute Journal, EPRI,Inc. (2009).

10. T.Nakata, K. Kubo and A. Lamont, "Design For Renewable Energy System With Application To Rural Area In Japan”, white paper. 